\title{
IMLEMENTASI PSIKOLOGI HUMANISTIK CARL ROGERS PADA TRADISI LOKAL NYADRAN DI JAMBE GEMARANG KEDUNGGALAR NGAWI
}

\author{
Wiwik Setiyani \\ Universitas Islam Negeri Sunan Ampel Surabaya, Indonesia \\ E-mail: wiwiksetiyani@uinsby.ac.id
}

\begin{abstract}
The article discusses nyadran celebration in the village of Jambe Gemarang Kedunggalar Ngawi with a humanistic psychology's Carls Rogers. The community welcomes the enthusiasm for nyadran, because the event has meaning for abangan community in carrying out the ritual. The enthusiasm of the community with the preparation of ritual ritual: gambyong dance complete with sinden (handlebar), tumpeng, cleansing, offerings and drinks. The purpose of nyadran is for the safety and well-being of the village community of Jambe Gemarang. The humanistic psychology of Carls Rogers contributes to analyzing the implementation of nyadran in building relationships or communications among citizens. The community's belief in rituals is significant, in particular the belief in sendang as a source of springs and large trees. The behavior of the people who believe in the ritual nyadran image of people who love local traditions and have a personality organism against the positive potentials of the community Jambe Gemarang. The nyadran ritual gives birth to a mature personality and a form of self-actualization of a prosperous society and has the pride of the nyadran tradition as (selfregard) formed from its experiences.
\end{abstract}

Keywords: Humanistic psychology; local tradition; nyadran.

\section{Pendahuluan}

Nyadran ${ }^{1}$ menjadi salah satu tradisi dan kebanggaan Desa Jambe Gemarang yang memiliki tujuan untuk bersih desa. Maksud bersih desa di sini adalah semacam ruwatan desa untuk menjauhkan diri dari rintangan atau hambatan untuk menghindari musibah yang akan

1 P. J. Zoetmulder dkk., Kamus Jawa Kuno Indonesia (Jakarta: Gramedia Pustaka Utama, 1982), 97. 
terjadi. $^{2}$ Masyarakat Desa Jambe Gemarang Ngawi menyakini bahwa ritual nyadran merupakan salah satu cara yang tepat untuk menemukan jati diri sekaligus membangun kerukunan dan solidaritas antar warga. Secara psikologis ritual nyadran membangkitkan kepercayaan diri ${ }^{3}$ untuk terus membangun desa dan tetap optimis bahwa setiap kendala yang dihadapi mampu diatasi secara bersama-sama.

Masyarakat Jambe Gemarang memiliki kepercayaan terhadap ritual nyadran yang mengalami proses regenerasi. Perubahan cara pandang terhadap pelaksanaan ritual terjadi pergeseran seiring perkembangan zaman. Masyarakat melaksanakan ritual sebagai warisan budaya yang diawali dengan kepercayaan terhadap mitosmitos $^{4}$ pada sendang dan pohon besar. Namun, kepercayaan tersebut telah berubah dan bergeser pada perilaku masyarakat terhadap hubungan solidaritas dan keyakinan kepada sang pencipta, yakni Tuhan yang Maha Kuasa. Untuk memahami keyakinan masyarakat Desa Jambe Gemarang, penulis menganalisis dengan kaca pandang psikologi humanistik. Hal ini karena terdapat aspek pengalaman dan kepercayaan yang diwariskan secara turun-temurun. Kepercayaan dan keyakinan masyarakat sangat beragam dalam menilai perayaan ritual nyadran ini. Beberapa subbahasan yang akan menguraikan seputar alasaan-alasan psikologis masyarakat Desa Jambe melaksanakan ritual nyadran, menjelaskan konstruksi psikologi humanistik perspektif Carl Rogers terhadap praktik nyadran, dan menjelaskan implementasi psikologi humanistik pada perayaan nyadran dan nilai-nilai humanistik dalam pembentukan kepribadian manusia melalui ritual nyadran.

Subbahasan di atas menarik untuk dikaji secara ilmiah dengan harapan praktik nyadran dapat dilestarikan sebagai budaya melalui pergeseran pemahaman serta diharapkan memberikan kontribusi tentang tradisi yang dapat dijadikan kebanggaan desa dengan membangun mental masyarakatnya dengan mengedepankan prinsipprinsip humanistik yakni, kepribadian, konsep diri dan aktualisasi diri.

\section{Konstruksi Psikologi Humanistik Carl Rogers}

Untuk memahami konstruksi psikologi humanistik perlu mengenal profil Carl Rogers. Ia adalah seorang tokoh psikologi

${ }^{2}$ Hasyim Hasanah, "Implikasi Psiko-sosio-religius Tradisi Nyadran Warga Kedung Ombo Zaman Orde Baru", Jurnal Wabana Akademika, Vol. 3 No. 2 (2016).

3 A.M. Hardjana, Penghayatan Agama: yang Otentik dan Tidak Otentik (Yogyakarta: Kanisius, 1993), 88.

${ }^{4}$ K.K. Ruthven, Myth (New York: Routledge, 1976), 71. 
humanistik yang mempelopori asosiasi psikologi humanistik. Nama lengkapnya Carl Ransom Rogers lahir pada tanggal 8 Januari 1902 di Oak Park Illinios Chicago. Carl termasuk tokoh yang tertarik dan rajin membaca al-Kitab. ${ }^{6}$ Kebiasaan Carl tersebut menjelaskan suatu perilaku yang dinamis untuk senantiasa belajar apapun termasuk agama. Carl memperoleh gelar master di bidang psikologi di Universitas Colombia tahun 1928. Tahun 1932, ia mendapatkan gelar doctor di bidang psikologi klinis di universitas yang sama. Karir pekerjaannya diawali dengan bekerja di Child Study Department of the Society for the prevention of Cruelty to Children (bagian studi tentang perhimpunan pencegahan tindak kekerasan pada anak). ${ }^{7}$ Kemampuan Carl tidak hanya berkutat pada dunia pendidikan, tetapi ia mampu mengimplementasikan dalam kehidupan sosial dengan bekerja di lembaga perlindungan anak.

Aktivitas Carl Rogers dalam melayani dan membantu anak-anak yang kurang perhatian orang tua serta mendorongnya untuk melakukan penelitian seputar problematika anak. Hasil penelitian Rogers berjudul The Clinical Treatment of The Problem Child yang mengantarkannya memperoleh tawaran menjadi pengajar di Universitas Ohio. Pada tahun 1942, Carl menjabat sebagai ketua American Psychological Society. ${ }^{8}$ Kreativitas Carl dalam mengembangkan dan menganalisis problem yang terjadi pada anak-anak mampu mengonstruksi teori psikologi humanistik sebagai puncak karyanya. Teori psikologi humanistik dapat diimplementasikan pada studi analisis tokoh khususnya tentang aktualisasi diri pada sisi lain, psikologi humanistik juga dapat digunakan untuk menganalasis tradisi pada kelompok masyarakat. Rogers mengungkapkan bahwa psikologi humanistik lebih berperan untuk memotivasi diri dan meningkatkan serta mengembangkan konsep diri, sementara psikologi humanistik Maslow lebih diarahkan pada kebutuhan dasar manusia. ${ }^{11}$

Psikologi humanistik disebut juga dengan psikologi kemanusiaan yang multifaset terhadap pengalaman dan tingkah laku manusia dengan

\footnotetext{
${ }^{6}$ Bau Ratu, "Psikologi Humanistik Carl Roegrs Dalam Bimbingan dan Konseling", Jurnal Kreatif, Vol. 17, No. 3 (2014).

${ }^{7}$ Richard House, Humanistic Psychology: Current Trend and Future Prospect (New York: Routledge, 2018), 18.

8 Ratu, Psikologi Humanistik", 1.

${ }^{11}$ Nugraha Arif Karyanta, "Self-esteem pada Penyandang Tuna Daksa", Jurnal Wacana Psikologi, Vol. 5. No. 9 (2013).
} 
fokus pada keunikan dan aktualisasi diri manusia. ${ }^{12}$ Ciri-ciri psikologi humanistik adalah mendorong untuk meningkatkan kualitas diri manusia melalui penghargaannya terhadap ragam potensi positif yang ada pada manusia. Esensi dari psikologi humanistik adalah memanusiakan manusia dengan segenap potensi asli yang dimilikinya. ${ }^{13}$ Pembahasan psikologi humanistik secara general memperhatikan pada aspek aktualisasi diri yakni, struktur kepribadian. Kepribadian manusia terdiri atas organisme dan kompetensi atau kemampuan/potensi yang dimiliki. ${ }^{14}$

Struktur kepribadian manusia menjelaskan tentang prinsip-prinsip dasar kepribadian, dinamika perkembangan kepribadian dan kepribadian yang sehat. ${ }^{15}$ Kepribadian manusia dikelompokkan menjadi empat paradigma di antaranya: paradigma psikoanalisis, paradigma traits, paradigma kognitif dan paradigma behavior. ${ }^{16}$ Ragamnya pengetahuan tentang paradigma kepribadian, maka fokus pembahasannya adalah kepribadian pada aspek perilaku atau behavior. Perilaku secara umum pengendalian respons bagi perilaku spontan dan meningkatkan perilaku positif serta membuat perilaku baru muncul melalui pembentukan kontrol atau tujuan. ${ }^{17}$ Memahami perilaku ini didasarkan pada perbedaan perilaku spontan dan perilaku proses yang keduanya memiliki relasi atau hubungan dengan intensitas dan perilaku. ${ }^{18}$ Karakter Perilaku terdapat dua kategori yakni, perilaku keras dan lembut yang dijelaskan oleh Skinner ${ }^{19}$ atau dalam perilaku terdapat organisme yakni, terdapat level perilaku keras. ${ }^{20}$ Organisme kepribadian manusia merupakan potensi-potensi yang tersimpan dan

12 Ratna Syifa'a Rahmahana, "Psikologi Humanistik dan Aplikasinya dalam Pendidikan", Jurnal El-Tarbawi, Vol. 1, No. 1 (2008).

13 Hikmawan, "Perspektif Filsafat Pendidikan terhadap Psikologi Pendidikan Humanistik", Jurnal Sains Psikologi, Vol. 6, No. 1 (2017).

14 Duane Schultz, Psikologi Pertumbuban Model-model Kepribadian (Yogyakarta: Kanisius, 1991), 86.

15 Supratiknya, Psikologi Kepribadian 2: Teori-teori Holistik Organismik Fenomenologis (Yogyakarta: Kanisius, 1993), 132.

16 Alwisol, Psikologi Kepribadian (Malang: UMM Press, 2016), 89.

17 Garry Martin, Modifikasi Perilaku: Makna dan Penerapannya (Yogyakarta: Pustaka Pelajar, 2015), 77.

18 Icek Ajzen, Attitude Personality and Behavior (New York: Open University Press, 2005), 2.

19 Skinner tokoh psikologi yang fokus pada kajian perilaku verbal. B.F. Skinner, Verbal Behavior (Cambridge: Prentice Hall. Inc, 2014).

20 Sara J. Shettleworth, Cognition, Evolution and Behavior (New York: Oxford University Press, 2005), 23. 
dapat dimunculkan melalui reaksi-reaksi dan respons yang mendukungnya yakni, pengalaman-pengalaman yang dimiliki mampu membawa emosi yang kuat berupa aktualisasi diri. Carl mendasarkan teori struktur kepribadian meliputi tiga elemen penting yakni, organisme, medan fenomena, dan self. ${ }^{21}$

Rogers menjelaskan perilaku manusia adalah sebagaimana mestinya sesuai konsep diri atau self yang membentuknya melalui seluruh pengalamannya. Kecenderungan manusia adalah mengaktualisasikan diri sesuai dengan yang diinginkannya. Selain itu, sebagian besar manusia memiliki gaya hidup konsumtif yang ingin diaktualisir melalui barang-barang yang dimiliki. ${ }^{22}$

Pada dasarnya tingkah laku manusia adalah bertujuan untuk memuaskan kebutuhan-kebutuhannya. Namun, hal itu tetap mengacu pada tiga bagian penting dalam dinamika kepribadian yakni; Pertama, penerimaan positif (positive regard) seseorang merasa puas menerima regard positif demikian juga sebaliknya, puas dapat memberi regard positif kepada orang lain. Kedua, konsistensi dan kesesuaian diri (self consistency and congruence). Organisme berfungsi untuk memelihara konsistensi (keajegan atau keadaan tanpa konflik) dari persepsi diri dan congruence (kesesuaian) antara persepsi diri dengan pengalaman. Ketiga, aktualisasi diri (self actualization), pakar psikoanalisis Sigmund Freud menjelaskan organisme sebagai sistem energi dan mengembangkan teori energi psikis ditimbulkan, ditransfer dan disimpan. Pandangan Rogers tentang organisme adalah terus menerus bergerak maj,u sehingga tujuan tingkah laku untuk mencapai aktualisasi diri yaitu; kecenderungan dasar organisme untuk aktualisasi diri untuk kebutuhan pemeliharaan (maintenance) dan peningkatan diri (enbancement). ${ }^{23}$

Secara general, kepribadian manusia mengkaji persoalan-persoalan yang terkait dengan perbedaan dalam penyesuaian diri pada organisme manusia atau potensi-potensi yang dimiliki manusia. Teori-teori kepribadian memiliki jangkauan yang luas dan orientasi yang lebih praktis $^{24}$ yakni, dapat memberikan nilai-nilai manfaat bagi manusia.

21 Annas Fitria Sa'adah, "Konsep Diri Dalam Gaya Hidup Konsumtif Perspektif Teori Kepribadian Carl R. Rogers" (Tesis--Universitas Gadjah Mada Yogyakarta, 2015).

22 Ibid.

23 Supratiknya, Psikologi Kepribadian 1: Teori-teori Psikodinamik (Klinis) (Yogyakarta: Kanisius, 1993), 280.

${ }^{24}$ House, Humanistic Psychology, 86. 
Karena itu, psikologi humanistik memiliki peran besar untuk mengkomunikasikan persoalan-persoalan kehidupan dengan cara-cara yang humanis termasuk persoalan tradisi. Psikologi humanistik Carl Rogers memberikan ruang yang luas untuk menganalisis problem budaya khususnya tradisi ritual nyadran. Pada aspek organisme kepribadian memiliki peran besar untuk mendorong manusia untuk terus berkarya dan mewujudkan karya tersebut sebagai bentuk aktualisasi diri manusia baik, secara mandiri maupun kelompok masyarakat yang terlibat sebagaimana pada masyarakat Jambe Gemarang pada perayaan nyadran.

\section{Profil Jambe Gemarang dan Perayaan Nyadran}

Masyarakat Desa Jambe Gemarang merupakan salah satu masyarakat yang melestarikan tradisi nyadran. Masyarakat Jambe Gemarang terdiri dari dua kelompok masyarakat yakni; komunitas santri dan komunitas abangan. ${ }^{25}$ Komunitas santri terdiri dari kelompok masyarakat yang berlokasi di sekitar Masjid al-Huda dengan jumlah minoritas, sementara komunitas abangan memiliki jumlah yang lebih banyak. Uniknya, tidak ada kesenjangan di antara komunitas masyarakat dalam melaksanakan aktivitas sosial keagamaan. ${ }^{26}$ Kehidupan masyarakat Jambe Gemarang kebanyakan sebagai petani dan buruh tani serta sebagian kecil menjadi pendidik guru SD (Sekolah Dasar).

Gambaran masyarakat tersebut menjelaskan bahwa perilaku masyarakat masih tergolong marginal atau komunitas yang terpinggirkan. ${ }^{27}$ Komunitas yang demikian, memiliki kecenderungan untuk terus melestarikan warisan nenek moyangnya termasuk tradisi nyadran. Karena itu, peneliti memiliki beberapa alasan untuk melakukan penelitian di desa Jambe Gemarang di antaranya: pertama, Jambe Gemarang memiliki tradisi lokal khususnya nyadran yang tetap dilestarikan, meskipun tidak banyak diminati oleh masyarakat setempat. Kedua, orang yang terlibat dalam kegiatan nyadran lebih banyak diikuti oleh pendatang dari desa lain. Ketiga, tokoh agama cenderung membiarkan dan tidak mengapresiasi kegiatan nyadran, meskipun menggunakan tuak dan gambyongan. Keempat, kemampuan

25 Clifford Geertz, The Religion of Java (London: The University of Chicago Press, 1976), 121.

${ }^{26}$ Partini, Wawancara, Jambe Gemarang 18 Oktober 2016.

${ }^{27}$ Lukman S. Thahir, "Islam Ideologi Kaum Tertindas: Counter Hegemoni Kaum Marginal dan Mustad'afîn”, Jurnal Studi Islamika Hunafa, Vol. 6 No. 1 (2009). 
kepala desa untuk mengkoordinasi masyarakat dalam perayaan nyadran berjalan dengan baik. Kelima, keyakinan kepala desa bahwa ritual nyadran harus dilaksanakan agar terhindar dari musibah. ${ }^{28}$

Masyarakat Jambe Gemarang masih melaksanakan tradisi nyadran dipelopori oleh kepala desa dengan melibatkan sebagian masyarakat yang masih menyukai tradisi tersebut. Kebanyakan yang mengikuti tradisi ritual nyadran adalah komunitas pendatang atau dari desa lain dan orang-orang yang berada di sekitar sendang kuburan atau makam. ${ }^{29}$ Komunitas Jambe Gemarang melaksanakan aktivitas ritual nyadran sebagai bentuk perilaku determinisme cultural yakni, warisan yang turun-temurun dan harus dilakukan oleh seorang kepala desa. Warisan ritual nyadran ${ }^{30}$ telah menjadi tradisi dan menjadi salah satu syarat yang wajib dilaksanakan dan tanggungjawab kepala desa. Kepala desa merasa terbebani sekaligus tersanjung, karena bertanggungjawab untuk pelaksanaan ritual nyadran dan kesuksesan acara sebagaimana disampaikan oleh warga masyarakat. Kepala desa memiliki tanggungjawab besar untuk terus melestarikan tradisi nyadran dan harus berjalan terus, meskipun terkadang mengalami kesulitan dalam pembiayaan. ${ }^{31}$

Seiring bertambahnya pengalaman kepala desa dalam pelaksanaan ritual nyadran, kendala pembiayaan tersebut dapat teratasi. Perilaku kepala desa dalam pelaksanaan ritual nyadran bagian dari bentuk tanggungjawab moral yang membentuk kepribadian alami ${ }^{32}$ dan telah melekat pada pribadi kepala desa untuk bertanggungjawab kepada seluruh warga masyarakatnya. Peran kepala desa mampu mengakomodir keinginan dan kebutuhan masyarakat dan menjalankan kewajibannya sebagai pemimpin desa. Kebersamaan menjalankan aktivitas kegiatan desa menunjukkan adanya harmoni sosial yang terbangun dengan baik diantara warga masyarakat tanpa mengenal perbedaan statu sosial maupun agama.

\footnotetext{
28 Tuak berarti minuman yang memabukkan dan gambyongan adalah tarian yang diiringi dengan gamelan dan diikuti dengan memberikan minuman tuak kepada lakilaki yang mengajak menari dengannya. Tutik Winarti, "Tari Golek Gambyong Gaya Yogyakarta”, Jurnal Resital, Vol. 11. No. 1 (2010).

${ }^{29}$ Slamet, Wawancara, Jambe Gemarang 17 Oktober 2016.

30 Joko Tri Laksono, "Fungsi Janggrung dalam Upacara Nyadran di Pantai Slili Tepus Gunung Kidul Yogyakarta”, Jurnal Harmonia, Vol. 9, No. 1 (2009).

${ }^{31}$ Lasiyem, Wawancara, Jambe Gemarang 19 Oktober 2016.

32 Larsen Randy dan David Buss, Personality Psychology: Domains of Knowledge about Human Nature (New York: McGrave-Hill, 2008), 89.
} 
Komunitas abangan yang mendukung dan terlibat terhadap pelaksanaan ritual nyadran adalah orang-orang yang menarik simpati dan punya kepentingan untuk ikut berpartisipasi pada kegiatan tersebut. Tujuan komunitas tersebut sangat beragam, diantaranya: pertama, meluapkan emosi untuk dapat bebas meminum tuak yang sudah lama ditunggu. Kedua, dapat menari dengan para penari atau ledhek yang cantik dan memberikan saweran uang. Ketiga, adanya harmoni sosial karena perlengkapan yang digunakan untuk perayaan dilakukan secara sosial yakni, iuran dengan jumlah nominal yang sama atau bantuan seikhlasnya. Keempat, tidak memaksakan kepada masyarakat yang tidak mengikuti perayaan nyadran sebagai bentuk penghormatan atau toleransi kepada kaum santri yang tidak menyukai ritual nyadran. ${ }^{34}$ Ragamnya tujuan masing-masing komunitas abangan dalam menyambut tradisi nyadran diwarnai dengan sikap beragam, diantaranya: ada yang optimis dan cuek atau biasa saja. ${ }^{35}$ Sikap yang beragam diantara komunitas tersebut disebabkan adanya kepentingan yang berbeda dari setiap individu dalam melihat tradisi ritual nyadran. Misalnya tokoh agama mengatakan, ritual nyadran tidak ada dalam ajaran Islam, tetapi nyadran bagian dari tradisi lokal yang dinyakini oleh orang-orang abangan yang belum paham tentang agama. Oleh karena itu, biarkan mereka melakukan ritual nyadran sesuai dengan keyakinannya. ${ }^{36}$ Sikap tokoh agama tersebut diwakili kaum santri yang bersikap membiarkan perayaan nyadran agar tidak terjadi pertentangan yang menimbulkan konflik antarwarga masyarakat, khususnya pada pelaksanaan tarian gambyong dan minuman tuak.

Tradisi nyadran menjadi salah satu tradisi Jawa yang memiliki makna keyakinan untuk menziarahi makam leluhur dan membersihkannya serta mendoakan arwah leluhur. Aktivitas nyadran biasanya dilakukan untuk menyambut datangnya bulan Ramadhan. Nyadran merupakan bentuk akulturasi Islam dengan tradisi Jawa yang terjadi secara terus menerus dari generasi ke generasi. Nyadran berasal dari kata sadran yang artinya ruwah Sha'ban ${ }^{38}$ yang dilaksanakan dengan rangkaian kegiatan dari pembersihan makam dan puncaknya slametan atau kenduri.

\footnotetext{
${ }^{34}$ Sumarsono, Wawancara, Jambe Gemarang 20 Oktober 2016.

35 Casram, "Membangun Sikap Toleransi Beragama dalam Masyarakat Plural", Jurnal Wawasan, Vol. 1, No. 2 (2016).

${ }^{36}$ Sumarsono, Wawancara, Jambe Gemarang 11 Oktober 2016.

38 Winter C.F. dkk., Kamus Kawi-Jawi (Yogyakarta: Gadjah Mada University Press, 2003), 34 .
} 
Akar sejarah tradisi nyadran berasal dari agama Hindu-Budha dari tradisi Craddha yang kemudian berubah bentuk pelaksanaannya setelah syiar Islam melalui walisongo. Penyelarasan antara tradisi Hindu-Islam dilaksanakan dengan pembacaan Yasin-Tahlil dan doa pada acara makan bersama yakni, slametan atau kenduri. Ritual nyadran merupakan aktivitas sosial keagamaan yang terjadi di masyarakat Jawa $^{39}$ yang mentradisi dan melekat di hati masyarakat. Kegiatan yang dilakukan secara berkala menjelang bulan Ramadhan menjadi ciri khas masyarakat Islam yang membentuk perilaku beragama, karena pengalaman keagamaan yang dimiliki. Pengalaman keagamaan melalui ritual nyadran memperkuat hubungan antarumat dan memperkuat keyakinan kepada Tuhan yang menciptakan alam semesta serta mengingat perjuangan para leluhurnya. Ikatan antarumat melalui acara nyadran melahirkan perilaku keagamaan yang mengesampingkan sikap prejudice dengan orang lain. ${ }^{40}$ Tradisi nyadran memiliki makna untuk menjaga keharmonisan hubungan sosial, karena mempertemukan masyarakat dalam satu kegiatan bersama. Hubungan emosional antarwarga masyarakat menumbuhkan perilaku kebersamaan, yakni rasa memiliki terhadap tradisi yang dilaksanakan. Keterlibatan antarwarga melalui tradisi nyadran akan membentuk pengalaman baru ${ }^{42}$ dalam memahami karakter masing-masing individu. Pengalamanpengalaman tersebut dapat membentuk kepribadian masing-masing individu dalam memahami tradisi ritual nyadran seperti pengalaman mistik, pengalaman interaksi sosial maupun pengalaman keagamaan yang dimiliki. Pengalaman mistik seperti dirasakan oleh partisipan ritual' pada saat pelaksanaan ritual nyadran melihat sendang merasakan ada seseorang yang tinggal di sana (yang tidak dapat dilihat oleh semua orang) untuk menjaga sumur, agar air sendang tetap jernih dan penuh. Oleh karena itu, di sendang diberikan sesaji (kembang setaman, telur ayam, beras dan minyak srimpi). ${ }^{43}$ Pengalaman mistik, oleh Abdul Muhaya, ini merupakan pengalaman yang paling tinggi dan hanya ada pada kesadaran di atas egonya (self beyond ego). ${ }^{44}$

\footnotetext{
${ }^{39}$ Hasanah, "Implikasi Psiko-sosio-religius".

40 Michele Argyle, The Psychology of Religious Behavior Belief and Experience (London: Routledge, 2007), 218.

42 Sukma Adi Galuh Amawidyati, "Religiusitas dan Psychological Well-Being pada Korban Gempa", Jurnal Psikologi, Vol. 34, No. 2 (2007).

43 Sungkono, Wawancara, Jambe Gemarang 20 November 2018.

44 Abdul Muhaya, "Konsep Psikologi Transpersonal Menurut Abu Hamid Muhammad al-Ghazali”, Jurnal at Taqaddum, Vol. 9, No. 2 (2017).
} 
Kesadaran yang berada di atas ego disebabkan kemampuan seseorang untuk menjelajah atau melintasi kesadaran yang rasional.

Selain pengalaman mistik, ada juga pengalaman interaksi sosial yang terbingkai pada solidaritas dan nilai-nilai gotong royong yang membentuk perilaku masyarakat yang berkarakter dan memiliki jati diri. Sikap saling mendukung dan berkontribusi melalui iuran untuk pelaksanaan ritual nyadran dibebankan kepada masyarakat desa, baik yang terlibat langsung maupun tidak langsung pada kegiatan ritual nyadran adalah wujud jati diri dan karakter warga masyarakat Jambe Gemarang yang mencintai kebersamaan dan keharmonisan. Hubungan masyarakat yang terjalin melalui ritual nyadran merupakan bentuk kepedulian sosial yang harus terus dijaga. Meskipun, alasan masyarakat sangat beragam atau berbeda-beda dalam memaknai ritual nyadran di Desa Jambe Gemarang.

\section{Implementasi Psikologi Humanistik Pada Perayaan Nyadran}

Psikologi humanistik Carl Rogers memberikan inspirasi bahwa manusia memiliki potensi-potensi yang dapat digali dengan cara-cara yang bijak melalui tradisi ritual nyadran. Potensi diri yang berupa intelektual, emosi dan sosial ${ }^{46}$ dapat membentuk kreativitas matlamat sebagai wujud aktualisasi diri manusia. Potensi diri manusia disebut juga pengembangan diri yang meliputi: jasmani dan rohani (intelektual, emosi dan sosial). ${ }^{47}$ Tradisi ritual nyadran merupakan pengembangan diri sekaligus aktualisasi diri masyarakat yang dilakukan secara bersama-sama yang dinyakini dan dibanggakannya. Kebanggaan terhadap tradisi nyadran telah melekat pada masingmasing individu karena, rasa kepemilikan dan keyakinan yang kuat untuk menunjukkan kepada masyarakat. Perencanaan untuk melaksanakan sebuah tradisi ritual merupakan bentuk emosi masyarakat yang terkondisi dengan cara-cara berpikir yang rasional dan bijaksana. Kebijaksanaan masyarakat dalam membangun kebersamaan melalui tradisi ritual nyadran melahirkan kerja-sosial yang dapat mendukung dan membuka pandangan individu, bahwa hidup harus bekerjasama untuk menghasilkan target yang dicapai.

\footnotetext{
46 Mohamad Fuad Othman, "Pendidikan Rohani Berasaskan Sains Al-Quran", Jurnal Comparative Education, Vol. 1, No. 1 (2017).

${ }^{47}$ Yuni Novitasari, "Bimbingan dan Konseling Belajar (akademik) dalam Perspektif Islam", Indonesian Journal of Educational Counseling, Vol. 1, No. 1 (2017).
} 
Secara psikologis, manusia menginginkan hasil kinerja tercapai sesuai target, sehingga diperlukan kreativitas dengan metode yang tepat sesuai dengan keyakinan agamanya (Islam). ${ }^{48}$ Karena itu, melalui tradisi ritual nyadran yang dilaksanakan oleh masyarakat Jambe Gemarang sebagai sebuah inspirasi untuk menemukan potensi diri yang tepat sesuai ajaran Islam. Diantara perubahan ritual nyadran adalah adanya bacaan doa Islam pada acara slametan atau kenduri di sendang dan dilanjutkan dengan makan bersama dan diakhiri dengan tarian gambyong. ${ }^{49}$ Perubahan ritual nyadran masih menyisakan kegelisahan bagi tokoh agama, namun belum dapat dikomunikasikan dengan pihak kepala desa. Perayaan ritual nyadran merupakan bagian dari potensi diri manusia pada setiap warga masyarakat desa Jambe Gemarang.

Potensi diri manusia yang terdapat pada setiap individu manusia memiliki kecenderungan untuk dapat tampil atau menonjolkan diri. Potensi diri merupakan fitrah manusia yang berada dalam organisme manusia untuk membangkitkan, mengolah dan mempertahankan kreativitasnya yang bekerjasama dengan akalnya. Akal tersebut mengantarkan manusia untuk menjadi manusia yang humanis, ${ }^{50}$ yakni semangat toleransi, menghargai, mencintai dan membangun kebersamaan. Potensi diri manusia dapat dilihat pada kolektivitas masyarakat dalam melaksanakan tradisi ritual yang tidak ingin kehilangan moment atau peristiwa pelaksanaan ritual nyadran. Kemampuan membangun kerjasama antarindividu, karena adanya kepercayaan yang kuat untuk menyatukan pandangan dalam mewujudkan ritual nyadran. Ritual nyadran menambah percaya diri masyarakat sebagaimana pengakuan dari partisipan ritual nyadran: "nyadran menambah rasa percaya diri, karena diyakini setelah melaksanakan ritual akan terasa kepuasan dan pikiran menjadi lebih senang". ${ }^{11}$ Perasaan senang warga terpuaskan melalui ritual nyadran sebagai salah upaya menggali potensi manusia dengan ekspresi ritual keagamaan.

\footnotetext{
48 Fuad Nashori, "Refleksi Psikologi Islami”, Jurnal Psikologi Islam, Vol. 1, No. 1 (2005), 33-42.

${ }^{49}$ Musringah, Wawancara, Jambe Gemarang 23 November 2016.

50 Ratnawati, "Aspek-aspek Kejiwaan dan Motivasi Manusia dalam Konsepsi Islam", Islamic Counseling: Jurnal Bimbingan dan Konseling Islam, Vol. 1, No. 1 (2017), 41-50.

${ }^{51}$ Suwarno, Wawancara, Jambe Gemarang 19 November 2016.
} 
Ritual nyadran memiliki pengaruh bagi manusia untuk mengekpresikan potensi dirinya dan menghasilkan kepribadian yang lebih percaya diri, sehingga berdampak pada perilaku efektif. ${ }^{52}$ Bentuk percaya diri dapat berupa bekerja dan menghasilkan rizki yang banyak dengan terus bercocok tanam, bahkan percaya diri dalam menghadapi segala sesuatu yang akan dilakukan. Rasa percaya diri memberikan dampak terhadap perilaku efektif untuk terus berusaha dan membuat perencanaan yang matang, sehingga menghasilkan sesuatu yang bermanfaat untuk dirinya dan keluarganya.

Implementasi psikologi humanistik melalui ritual nyadran memberikan sebuah pelajaran berharga, bahwa setiap perilaku atau tindakan manusia memerlukan kerjasama antarindividu dan membentuk kelompok kerja, karena potensi diri manusia tidak dapat ditemukan secara spontan tanpa adanya kerjasama dan keyakinan serta dukungan masyarakat. Dukungan para orangtua ${ }^{53}$ atau sesepuh desa, bahkan perangkat desa menjadi alasan yang tidak dapat diabaikan. Hal ini karena ritual nyadran bagian dari warisan leluhur yang harus dilestarikan serta kekuatan kepercayaan diri masyarakat. Kepercayaan diri akan muncul, jika terdapat sebuah aktivitas yang dapat membuat simpati atau menarik dirinya untuk mengikuti aktivitas kegiatan ${ }^{54}$ tersebut dan membuat merasa nyaman dan senang sebagaimana kepercayaan diri dan rasa senang yang terjadi pada masyarakat Jambe Gemarang pada pelaksanaan ritual nyadran. Kepercayaan diri dalam pelaksanaan ritual membangkitkan semangat dan menumbuhkan kepribadian pada setiap pelaku ritual. Kepribadian manusia terbentuk oleh sebuah pengetahuan dan keterlibatan dalam suatu aktivitas. ${ }^{55}$ Karena, aktivitas memberikan pembelajaran hidup untuk membentuk dan mengubah perilaku. Kepribadian manusia ini didasarkan pada

52 Lailatul Fitriyah etc., "Effectiveness Behavioral Coating with Modeling Techniques and Assertive Training Techniques to Increase Confidence", The Bisma Journal, Vol. 1, No. 1 (2017).

${ }_{53}$ Nurul Fadhilah Siregar, "Hubungan Kepercayaan Diri dan Dukungan Orangtua dengan Kemampuan Membuat Aksesoris dari Limbah Kulit Jagung Siswa SMP Negeri 34 Medan" (Skripsi-Universitas Negeri Medan Medan, 2017).

${ }^{54}$ Rizqy Kusuma Lestari dan Sri Sularti Dewanti Handayani, "Children Confidence Development by Theme Based Movement and Singing Method at RA Islamic Tunas Bangsa 4 Ngaliyan Semarang", BELIA: Early Childhood Education Papers, Vol. 6, No. 1 (2017).

${ }_{55}$ M. Ridwan Hisda, "Implementasi Pembelajaran Tafsir Alquran Pada Fakultas Agama Islam Universitas Dharmawangsa Medan”, Edu Riligia: Jurnal Ilmu Pendidikan Islam dan Keagamaan, Vol. 1, No. 3 (2017). 
kepercayaan, ikatan sosial, ideologi dan personalitas ${ }^{56}$ melalui empat komponen tersebut melahirkan ekspresi budaya sebagaimana ekspresi ritual nyadran di Jambe Gemarang.

Rogers menjelaskan bahwa dalam kepribadian manusia terdapat organisme, yakni kesatuan fisik dan psikis yang memiliki beragam fungsi. Fungsi organisme adalah sebagai tempat memperoleh beragam peristiwa yang dialami dan menjadi sumber pengalaman-pengalaman baik disadari maupun tidak disadari dan membentuk medan fenomenal. ${ }^{57}$ Pada ritual nyadran masyarakat Jambe Gemarang memiliki keyakinan, bahwa pengalaman mistiknya mampu membuat dirinya semakin percaya diri dan membentuk kepriabadian yang utuh. Selanjutnya, kepribadian sebagai self-concept (konsep diri) Rogers mengartikan persepsi karakteristik dengan orang lain atau berbagai aspek kehidupan termasuk nilai-nilai keyakinan, kenyataan, tingkah laku atau gambaran mental diri sendiri, dengan demikian self concept menjadi acuan utama dalam membentuk karakter manusia, karena dominan dalam pencapaian hidup. ${ }^{58}$ Self concept dapat dicapai melalui interaksi sosial baik dalam lingkungan internal keluarga ataupun dalam dunia akademik, bahkan di kelas sekalipun atau dalam berbagai kegiatan aktivitas sosial. Interaksi sosial memiliki pengaruh besar untuk membentuk konsep diri, karena lingkungan sosial memiliki ragam pengalaman-pengalaman dan menjadi kisah-kisah atau cerita yang melekat pada setiap manusia. Sejarah dan pendidikan menjadi referensi utama dalam membentuk konsep diri, karena cara-cara berpikir yang kreatif dan pengetahuan ${ }^{60}$ yang diperoleh menjadi modal utama untuk diimplementasikan di masyarakat.

Karakter dan mental yang telah dibentuk dengan pengalamanpengalaman dari pelaksanaan ritual nyadran, maka melahirkan potensipotensi baru berupa aktualisasi diri manusia. Persepsi individu tentang aktualisasi diri merupakan fungsi motivasi yang berhubungan dengan

\footnotetext{
${ }^{56}$ Endy Marlina dan Arya Ronald, "Ekspresi Budaya Membangun pada Masyarakat Jeron Beteng Kecamatan Kraton Yogyakarta", Jurnal Humaniora, Vol. 23, No. 2 (2011), 150-165.

57 Carl Rogers, Some Observations on the Organization of Personality (New York: American Psychologys, 2000).

${ }^{58}$ Richard J. Shavelson, "Self-Concept: The Interplay of Theory and Methods", Journal of Educational Psychology, Vol. 74, No. 1 (1982), 3-17.

${ }^{60}$ Richard J. Shavelson, "Selt Concept: Validation of Construct Interpretations", Sage Journal, Vol. 46, No. 3 (1976).
} 
seluruh potensi manusia yang dimiliki.$^{61}$ Aktualisasi diri manusia dapat terwujud didukung oleh motivasi yang kuat sebagaimana pelaksanaan ritual nyadran di Jambe Gemarang. Tokoh masyarakat dituntut untuk melestarikan ritual nyadran setiap tahunnya dalam kondisi apapun. Kepercayaan dan menjaga amanah dari warisan budaya menjadi alasan sekaligus motivasi kuat, sehingga melahirkan kreativitas yang memerlukan dukungan atau support untuk merealisasikan ritual nyadran di Jambe Gemarang. Motivasi yang optimal dalam bekerja melahirkan hasil kinerja yang maksimal sesuai dengan tujuan yang ingin dicapai, sehingga aktualisasi diri yang dimunculkan juga memiliki dampak positif bagi dirinya dan lingkungannya. Aktualisasi diri dapat diwujudkan dalam beragam bidang seperti pendidikan atau akademik, ekonomi, sosial, budaya, agama, bahkan dalam dunia kecantikan sebagaimana tulisan tentang self-actualization and the tragedy of beauty yang menjelaskan bahwa aktualisasi diri merupakan ruang publik yang memberikan dampak psikologis.

Aktualisasi diri dalam budaya sebagaimana pelaksanaan ritual nyadran yang dilakukan oleh masyarakat Jambe Gemarang, masingmasing individu berperan untuk terlibat dalam perayaan dan ritual. Bentuk-bentuk aktualisasi diri masyarakat adalah dengan menjadi pemimpin acara dan doa bersama yang dilanjutkan dengan menari gambyong serta meminum tuak (ritual nyadran selalu ada tarian gambyong dan minum tuak). ${ }^{64}$ Ragam aktualisasi diri yang digambarkan masyarakat Jambe Gemarang merupakan salah satu implementasi psikologi humanistik yang dipraktikkan melalui ritual nyadran yang dapat berpengaruh pada nilai-nilai penghargaan dan kreativitas yang dapat membentuk kepribadian manusia yang humanis. Kerjasama, solidaritas dan penghargaan setiap perilaku memiliki nilai-nilai pengalaman yang membentuk kepribadian individu. Perilaku masyarakat lebih humanis pada saat demonstrasi perayaan nyadran. Ini karena kerjasama diantara pelaku ritual nyadran dapat membentuk konsep diri secara sistematis dan mampu mengekspresikan dirinya dengan aktivitas lainnya seperti gotong royong dan tidak memaksakan orang-orang yang tidak berkenan mengikuti perayaan nyadran. Lebih dari itu, adanya praktik minum-minuman tuak yang menjadi faktor

${ }^{61}$ J.A. Krems, DT. Kenrick, R. Neel, "Individual Perceptions of Self-Actualization: What Functional Motives Are Linked to Fulfilling One's Full Potential?”, Pers Soc Psychol Bull, Vol. 43, No. 9 (2017).

${ }^{64}$ Suyono, Wawancara, Jamber Gemarang 18 November 2016. 
"resistensi" dari pihak lain yang tidak berkenan terlibat langsung dalam ritual nyadran.

Sikap tersebut telah menginternalisasi para pelaku ritual, ${ }^{65}$ bahwa perayaan nyadran tidak diajarkan dalam Islam. Berbeda halnya dengan sebagian masyarakat lainnya yang masih melaksanakan ritual tersebut karena berkeyakinan animisme dan dinamisme yang dipengaruhi oleh tradisi agama Hindu dan Budha. ${ }^{66}$ Masyarakat Jambe Gemarang yang menganut agama Islam masih melaksanakan ritual nyadran sebagai bentuk determinism cultural yang tidak dapat dihilangkan, karena menyakini ritual ini adalah bagian dari upaya meneruskan amanah nenek moyangnya. ${ }^{67}$ Masyarakat Jambe Gemarang senantiasa menghormati dan menghargai pendapat terkait perayaan ritual nyadran. Bagi mereka yang terpenting kerukunan dan kebersamaan antarmasyarakat tetap terjaga. Konsep diri tentang penghargaan dan solidaritas juga kerjasama telah melekat pada masyarakat Jambe Gemarang, karena implementasi sebuah pengalaman ritual bukanlah sekadar berhura-hura saja, tetapi perilaku humanis dan saling mendukung merupakan manifestasi dari psikologi humanistik.

\section{Nilai-nilai Humanistik Pembentukan Kepribadian Manusia Melalui Interaksi Sosial Ritual Nyadran}

Ritual nyadran di Jambe Gemarang dapat menumbuhkan semangat kebersamaan dan melahirkan nilai-nilai humanisme agama. ${ }^{68}$ Karena ritual nyadran memiliki nilai sejarah dan kearifan lokal bagi masyarakat Jambe Gemarang. Sejarah nyadran di Jambe Gemarang hanya sebagai mitos (motivasi seseorang untuk melakukan sesuatu termasuk ritual nyadran), ${ }^{69}$ tetapi tetap dinyakini kebenarannya oleh tokoh masyarakat

65 Achmad Faqihuddin, "Internalisasi Nilai-nilai Humanistik Religius pada Generasi Z Dengan "Design for Change", Edukasia: Jurnal Penelitian Pendidikan Islam, Vol. 12, No. 2 (2017), 263-280.

66 Ryko Adiansyah, "Persimpangan antara Agama dan Budaya: Proses Akulturasi Islam dan Slametan dalam Budaya Jawa", Jurnal Intelektualita: Keislaman, Sosial, dan Sains, Vol. 6, No. 2 (2017), 295-310.

${ }^{67}$ Slamet, Wawancara, Jambe Gemarang 12 Desember 2016.

68 Ahmad Wafi Muzaki, "Humanisme Religious Sunan Drajat sebagai Nilai Sejarah dan Kearifan Lokal", Prosiding Seminar Nasional Pemanfaatan Smartphone untuk Literasi Produktif (2017).

${ }^{69}$ Mitos merupakan motivasi masyarakat untuk melakukan sesuatu; motivasi dapat berupa mendapatkan sumber ekonomi yang lebih banyak, motivasi mencari pasangan, motivasi untuk mencari kepuasan dan lain-lain. Muhammad Roy Purwanto dan Sularno, "Motivasi Ziarah di Makam Pangeran Samudra di Gunung 
khususnya kepala desa. Keyakinan terhadap mitos tidak menjadi hambatan untuk tetap melaksanakan ritual nyadran: "sebenarnya kami melakukan ritual nyadran hanya sekadar menjalankan saja, agar tidak mendapat musibah". ${ }^{70}$ Pelaksanaan aktivitas ritual tidak mendapatkan hambatan bahkan terlaksana dengan baik, karena sikap kepala desa yang mampu menyakinkan masyarakatnya, untuk menciptakan kebersamaan, kerjasama dan gotong-royong serta saling mendukung menjadi tujuan setiap warga masyarakat.

Alasan utama praktik nyadran agar terhindar dari musibah telah menjadi motivasi kepala desa Jambe Gemarang sekaligus menjadi konsep diri untuk mengaktualisasikan tradisi ritual nyadran. Pelaksanaan ritual nyadran terdapat sebagian warga yang ingin terlihat menonjol dan mendapatkan perhatian, khususnya bagi peminum tuak. Padahal praktik ini dapat berdampak negatif bagi kesehatannya. Sikap dan perilaku peminum tuak dalam ritual nyadran menggambarkan kesenangan alam ketidaksadaran manusia yang tidak terkendali. Konsep diri yang dimiliki hanyalah mencapai kepuasan, sehingga agama tidak dapat berperan dalam kehidupan mereka. ${ }^{71}$ Perilaku peminum tuak yang mabuk merupakan sifat manusia yang ingin selalu menonjol dan mendapat respons serta apresiasi dari masyarakat, bahkan, menjadi cerita unik yang dapat mewarnai kelancaran dan kesuksesan ritual nyadran. ${ }^{72}$

Sikap ini bagian dari ego manusia yang ingin menonjol atau tampil berbeda dengan lainnya. Ego merupakan ketidaksadaran pribadi dan menjadi ketidaksadaran kolektif serta ditemukan kepribadian yang introvert. ${ }^{73}$ Masyarakat Jambe Gemarang yang terlibat pada ritual perayaan nyadran masih mengedepankan emosi semata dengan mendahulukan kesenangan yang didukung dengan minuman tuak, sehingga alam ketidaksadaran telah mendominasi dalam kepribadian pelaku ritual nyadran.

Kemukus dan Mitos Ritual Hubungan Seks", https://dspace.uii.ac.id/handle/ 123456789/4126/Diakses 20 Januari 2018.

${ }^{70}$ Kosemin, Wawancara, Jambe Gemarang 21 November 2016.

71 Maghfur Ahmad, "Agama dan Psikoanalisa Sigmund Freud”, Religia: Jurnal Ilmuilmu Keislaman, Vol. 14, No. 2 (2009), 279-290.

72 Marwan, Wawancara, Jambe Gemarang 11 Desember 2016.

73 Elva Yusanti, "Struktur Kepribadian Tokoh Utama dalam Novel Nyali Karya Putu Wijaya”, Mlangun: Jurnal Ilmiah Kebahasaan dan Kesastraan, Vol. 12, No. 2 (2016), 477-489. 
Sementara pada aspek super-ego ${ }^{74}$ pada kepribadian manusia sebagai pengendali sekaligus filter moralitas manusia berperan penting dalam pembentukan perilaku manusia yang religius dan mengedepankan nilai-nilai etika dan estetika masyarakat. ${ }^{75}$ Para pelaku ritual yang terlibat dalam ritual nyadran masih menyisakan beberapa orang yang tidak mampu mengendalikan diri untuk berprilaku tidak santun dengan mabuk yang berlebih-lebihan, sehingga ungkapan kata yang dikeluarkan juga tidak layak didengar oleh masyarakat yang hadir. Sikap yang kurang bijaksana dalam perayaan ritual nyadran, khususnya pada acara tari gambyongan dianggap sebagai perkecualian yang berada di luar kesadaran manusia.

Perilaku masyarakat dalam pelaksaan ritual nyadran tidak dapat dikendalikan oleh tokoh agama maupun tokoh masyarakat (kepala desa), jika tarian gambyongan dilakukan dalam kondisi mabuk. Oleh karena acara tersebut harus dihentikan sejanak untuk menetralisir suasana. Anehnya, bagi masyarakat, pelaksanaan nyadran dianggap berhasil bila pesert ritual nyadran mengalami kondisi mabuk. ${ }^{76}$ Keyakinan tersebut menimbulkan problem bagi tokoh agama yang kurang berkenan pada pelaksanaan ritual nyadran. Namun, belakangan secara perlahan dapat dihindari bahkan dihilangkan keyakinan tentang mabuk dalam ritual nyadran.

Pada konteks ini, kemampuan mengendalikan diri antara ide, ego dan super ego pada kepribadian manusia, karena adanya proses keseimbangan yang terjadi antara emosi dan kesenangan serta moralitas masyarakat menjadi relevan. Kepribadian yang sehat dapat dilihat dari keseimbangan antara ide, ego dan super-ego. ${ }^{77}$ Kepribadian yang sehat memberikan nilai positif bagi lingkungan sekitar terutama pada nilai-nilai kepedulian sosial dalam melihat beberapa peserta nyadran yang tidak terkontrol emosinya.

Kecenderungan masyarakat Jambe Gemarang pada pelaksanaan ritual nyadran telah memberikan perhatian dan keamanan serta perlindungan bagi peserta nyadran yang 'mabuk tuak' pada acara tarian gambyong. Bagi pelaku yang mabuk mendapat apresiasi atau

\footnotetext{
${ }^{74}$ Gideon Karen (ed.), a Handbook for Data Analysis Behavioral Sciences: Methodological Issues (New York: Psychology Press, 2009), 311.

${ }^{75}$ John C. Harsanyi, "Morality and the Theory Rational Behavior", JSTOR, Vol. 44, No. 4 (1977).

${ }^{76}$ Slamet, Wawancara, Jambe Gemarang 23 Desember 2016.

${ }^{77}$ Lisnawati dan Yunus, "Analisis Tokoh Utama dalam Novel Ashmora Paria Karya Herlinatiens: Psikoanalisis Sigmund Freud”, Jurnal Bastra, Vol. 1, No. 4 (2017), 1-20.
} 
penghargaan dari kepala desa karena totalitas dalam pelaksanaan nyadran sebagai partisipan. ${ }^{78}$ Penghargaan terhadap pelaku nyadran bagian dari sikap penghormatan dan self-regard ${ }^{79}$ tanpa memandang siapa yang memperoleh. Sikap tersebut menimbulkan reaksi positif dan mempermudah bagi pemabuk (saat gambyongan pada ritual nyadran) untuk adaptasi. Hal ini karena adanya penerimaan diri dengan lingkungan sekitar serta bimbingan agar secepat mungkin melakukan penyesuaian diri, sehingga self-esteem ${ }^{80}$ manusia dapat dikembalikan melalui self-regard. Nilai-nilai humanis dapat dilihat pada pembentukan kepribadian masyarakat yang benar-benar menghargai perubahan sikap seseorang dari posisi spontan yang kurang diterima nilai-nilai moralitas namun, mampu diredam oleh sikap yang humanis dari kepala desanya. Perilaku kepala desa mendapatkan simpatik dan apresiasi masyarakat yang mampu memberikan nilai-nilai penghargaan kepada yang lain dan dapat bersikap bijak dengan kaum santri yang berbeda pandangan tentang nyadran.

Kebijaksanaan kepala desa telah menginspirasi masyarakat Jambe Gemarang untuk tidak semena-mena dengan orang-orang yang berbeda pandangan atau pendapat tentang apapun. Perilaku pemimpin desa memberikan semangat dan rasa percaya diri setelah proses pelaksanaan ritual nyadran berakhir. Kepercayaan masyarakat terhadap ritual ini dapat terjadi pada berbagai daerah yang dapat menimbulkan dampak positif terutama memberikan semangat dan rasa percaya diri masyarakat. ${ }^{81}$ Kepercayaan diri masyarakat Jambe Gemarang didukung oleh kepala desa yang dianggap memiliki karismatik dalam memimpin masyarakat. Karisma kepala desa dapat dilihat dari cara-cara memimpin dan menyelesaikan problem yang dihadapi masyarakat. Misalnya, kebijaksanaan dalam mengambil keputusan untuk bersama-sama berkontribusi dalam perayaan nyadran, baik terlibat langsung maupun tidak langsung. ${ }^{82}$ Kebijaksanaan kepala

\footnotetext{
${ }^{78}$ Kusman, Wawancara, Jambe Gemarang 28 Desember 2016.

${ }^{79}$ M. Alexis, "Prominents Feeling and Self-regard Among Survivor of Suicide Does Time Heal All Wounds", Sage Journal, Vol. 25, No. 3 (2017).

80 Nidia Suryani, "Hubungan Self Esteem dengan Sikap Sosial Remaja Serta Implikasinya dalam Layanan Bimbingan dan Konseling di SMA Dabiah Padang", Ristekdik: Jurnal Bimbingan dan Konseling, Vol. 3, No. 1 (2017), 23-30.

81 Cahyo Budi Utomo dan Ganda Febri Kurniawan, "Bilamana Tradisi Lisan Menjadi Media Pendidikan Ilmu Sosial di Masyarakat Gunungpati”, Jurnal Harmony, Vol. 2, No. 2 (2017), 169-180.

82 Marwan, Wawancara, Jambe Gemarang 29 Desember 2016.
} 
desa dalam memimpin masyarakat mampu mengedukasi masyarakat dalam mengambil keputusan sebagai pemimpin transformasional, ${ }^{83}$ karena mampu membaca kondisi masyarakat baik dalam tinjauan sejarah nyadran sebagai warisan tradisi dan Islam tidak rigid dalam menilai tradisi lokal nyadran. Karisma kepala desa bukanlah dari perolehan orangtuanya, tetapi kemampuan yang diperoleh atas usahanya, sehingga ia disebut sebagai tokoh masyarakat. Kebanyakan karisma pemimpin diperoleh karena elit agama, elit pesantren dan tokoh masyarakat yang mampu menyebarkan pengetahuan agama Islam. ${ }^{84}$ Hal ini berbeda dengan kepala desa Jambe Gemarang yang mampu memimpin masyarakat secara bijaksana karena nyadran bukanlah satu-satunya ritual yang harus diselenggarakan. Namun, terdapat beragam aktivitas lainnya seperti pengajian setiap dua minggu sekali, aktivitas kesehatan para manula dan posyandu anak-anak setiap dua bulan, bahkan pertemuan rutin kelompok tani setiap bulan untuk mengevaluasi kondisi pertaniannya. ${ }^{85}$

Keharmonisan masyarakat Jambe Gemarang tercermin dari setiap aktivitas sosial yang dilakukan, sehingga popularitas masyarakat Jambe tersebar di berbagai daerah lainnya, hingga Kabupaten Ngawi. Kepribadian masyarakatnya mencerminkan nilai-nilai humanis yang peka terhadap lingkungan khususnya partisipasi masyarakat terhadap ritual nyadran. Interaksi sosial yang dibangun pada ritual nyadran mencoba mensinergikan antara tradisi lokal dengan ajaran Islam ${ }^{86}$ melalui ritual doa bersama. Kepribadian masyarakat Jambe Gemarang dibentuk melalui ritual nyadran (nilai-nilai kerjasama, penghargaan, toleransi, saling mendukung) yang melahirkan nilai-nilai humanis dengan memandang manusia sebagai makhluk tertinggi ${ }^{87}$ apapun status sosialnya. Interaksi sosial melalui perayaan nyadran membentuk pribadi yang humanis dan mampu menghilangkan problem-problem yang dihadapi karena perbedaan pendapat diantara warga masyarakat.

83 Syaifur Rahman, "Kepemimpinan Transformasional di Lembaga Pendidikan: Kajian Sejarah, Psikologis, dan Pandangan Islam tentang Kepemimpinan”, Junal Humanistika: Jurnal Keislaman, Vol. 3, No. 1 (2017).

84 Edi Susanto, "Krisis Kepemimpinan Kiai: Studi atas Kharisma Kiai dalam Masyarakat, Islamica: Jurnal Studi Keislaman, Vol. 1 No. 2 (2007), 111-120.

${ }^{85}$ Kumini, Wawancara, Jambe Gemarang 13 Desember 2016.

86 Siti Mahmudah, "Mensinergikan Nilai-nilai Keagamaan dengan Tradisi Lokal sebagai Upaya Mewujudkan Masyarakat Madani: Studi Kasus Komunitas Kejawen di Desa Bajulan Kecamatan Loceret Kabupaten Nganjuk", Jurnal Konseling dan Pendidikan, Vol. 5, No. 1 (2017).

87 Al-Qur'ān: 95: 4. 
Perayaan nyadran menjadi media yang tepat untuk membangun hubungan yang humanis serta meningkatkan percaya diri karena, motivasi yang membentuk potensi-potensi diri masyarakat yang sejahtera.

\section{Analisis Aktualisasi Diri Psikologi Humanistik terhadap Ritual Nyadran}

Psikologi humanistik Carl Rogers memberikan kontribusi dalam menganalisis ritual perayaan nyadran di desa Jambe Gemarang. Ritual nyadran merupakan bentuk aktualisasi diri masyarakat yang diperoleh berdasarkan pengalaman-pengalaman yang diikuti sejak kecil dan diajarkan oleh orang-orang terdahulu atau sebelumnya. Pengalamanpengalaman tersebut membekas dan melekat pada setiap pribadi manusia. Setiap individu memiliki cara yang berbeda dalam memaknai ritual nyadran, sehingga melahirkan ragam kepribadian. Kepribadian sendiri terdiri dari struktur organisme yakni emosi, pengalaman dan potensi-potensi positif yang membentuk motivasi manusia. Komponen tersebut melahirkan karakter kepribadian manusia yang menghargai dirinya self-regard dan penerimaan diri self-esteem. Dorongan manusia untuk melakukan sesuatu disebabkan kepentingan manusia atau mengutamakan kepentingan manusia sesuai dengan potensinya. Potensi-potensi manusia tersebut berupa kekuatan pengalaman dan cara-cara berpikir yang rasional dan dapat diwujudkan. ${ }^{88}$

Psikologi humanistik Rogers dalam membangun kepribadian memiliki kekuatan yakni, pengalaman subjektif individu dan kekuatan berpikir manusia, sehingga ia sebagai mahkluk tertinggi yang harus memiliki self-regard dan self-esteem, tetapi mengabaikan spiritualitas manusia yang dalam istilah disebut psikologi transpersonal. Kepribadian manusia dibentuk bukan hanya pada aspek fisik dan psikis saja, melainkan, aspek spiritual yakni, agama tetap berperan dalam membentuk kepribadian.

Kepribadian masyarakat Jambe lebih mengedepankan pada aspek emosi diri, khususnya puncak pencapaian ritual nyadran pada praktik minum tuak, masyarakat Jambe Gemarang menyebutnya dengan lakon. ${ }^{89}$ Seseorang yang telah mencapai lakon, maka seluruh potensi

88 Septi Gumiandari, "Kepribadian Manusia dalam Perspektif Psikologi Islam: Telaah Kritis atas Psikologi Modern”, Jurnal Holistik, Vol. 12, No. 1 (2011).

89 Istilah lakon berarti orang yang telah mencapai puncaknya nyadran dengan diakhiri gambyong. Slamet, Wawancara, Jambe Gemarang 12 Desember 2016. 
diri telah tersalurkan. Ini karena organisme mendorongnya dan wujud dari aktualisasi diri. Rogers memberikan ruang yang luas kepada seluruh potensi manusia, karena manusia memiliki hak penuh untuk mengekspresikan dirinya. Perilaku tersebut menunjukkan adanya persistensi seseorang sebagai kekuatan karakter ${ }^{90}$ dan kehendaknya (the power of will). Manusia memiliki kehendak untuk mendorong dan menunjukkan eksistensi diri sebagai bentuk aktualisasi diri. Namun, harus dibatasi oleh norma-norma yang membatasi dirinya.

Psikologi humanistik Rogers seharusnya tidak hanya fokus pada seluruh potensi manusia atau organisme kepribadian yang diwujudkan pada aktualisasi diri, tetapi mengabaikan nilai-nilai integral dari psikologi. Perspektif integral merupakan pencapaian seseorang (self) tentang kebaikan dari dalam inner dan tercermin pada organisme kepribadian. Aspek spiritual menjadi salah satu problem untuk mempertemukan psikologi barat dan psikologi Timur harus saling melengkapi dalam melihat dan memahami psikologi humanistik secara komprehensif..$^{11}$ Aktualisasi diri Rogers belum memperhatikan aspekaspek local wisdom, tetapi fokus pada client centered yang harus dievaluasi. Artinya, lakon dalam ritual nyadran mengabaikan nilai-nilai inner atau kebaikan untuk dapat mengendalikan diri, agar tidak menjadi lakon. Kelancaran dalam ritual nyadran bukan terletak pada self 'lakon,' tetapi harus disempurnakan dengan melakukan perubahan pada pemahaman lakon.

Penyempurnaan pada ritual nyadran dapat dilakukan dengan mengedepankan aspek spiritual dan norma-norma yang berlaku umum bukan sekadar mendepankan humanis, tetapi kepribadian manusia harus dapat dikendalikan oleh nilai-nilai inner (kebaikan diri). Artinya, self-esteem itu bukanlah sekadar menerima kondisi apapun, melainkan organisme mampu mengendalikan dan mencegah, agar keyakinan warisan budaya tentang lakon tidak dipahami secara personal, tetapi berlaku universal baik dari kalangan abangan dan santri.

Dengan demikian, memahami ritual nyadran dapat dilakukan dengan mengedepankan nilai-nilai edukasi bagi masyarakat yakni kesalehan ritual, kesalehan sosial, dan keasalehan perilaku. ${ }^{92}$ Kesalehan

\footnotetext{
${ }^{90}$ Steven C. Hetler, "Personal Persistensi and its Absence in Contemporary Life Narrative”, Sage Journal, Vol. 57, No. 2 (2017).

${ }^{91}$ Brant Cortright, Integral Psychology (New York: New York Press, 2007), 13.

92 Abdul Basir, "Nilai Pendidikan Islam dalam Budaya Tenongan Nyadran Suran di Dusun Giyanti Wonosobo", Junal al-Qalam, Vol. 9, No. 2 (2012).
} 
ritual misalnya, tarian gambyong tidak harus dibarengi dengan minum tuak. Akan tetapi justru dapat dijadikan media untuk lomba seni budaya antar desa dalam rangka nyadran doa bersama dengan warga dengan melibatkan semua unsur baik tokoh agama atau ulama, tokoh masyarakat dan perangkat desa. Hal ini dapat dilakukan agar agar tidak terkesan didominasi warga tertentu.

Aktualisasi diri merupakan salah satu cara untuk menunjukkan bahwa seseorang memiliki kemampuan untuk eksistensi diri agar orang lain memahami dan mengerti tentang kemampuan dirinya. Aktualisasi diri Rogers menyisakan problem dari aspek partikular manusia yakni, sifat manusia yang memerlukan bimbingan dalam memahami prinsip yang salah. Prinsip melestarikan tradisi dan menjalankan amanah para pendahulu atau orang tua adalah sesuatu yang harus dijalankan dengan baik. Akan tetapi, prinsip tersebut jika bertentangan dengan ajaran agama yang menjadi pedoman umat Islam, maka harus dihindari bahkan dihilangkan. Oleh karena itu, kepribadian manusia tidak hanya bertumpu pada aspek humanisme an-sich, tetapi, aspek religusitas yang menyakini dan percaya (belief) kepada agama Allah dan pengalaman keagamaannya. ${ }^{93}$ Ajaran agama bukan sekadar spiritualitas dalam perspektif psikologi transpersonal, tetapi lebih mengarah kepada aspek-aspek religiositas, sehingga prinsip ritual nyadran dapat dipahami secara komprehensif oleh seluruh umat beragama dan masyarakat.

Memahami aktualisasi diri Carl Rogers pada tradisi lokal ritual nyadran merupakan prinsip humanisme yang mengapresiasi seluruh potensi manusia dan self-regard yang luar biasa. Namun, pada aspek selfesteem bentuk psikologi transpersonal belum dapat diterima oleh kelompok partikular khususnya pada aspek religiositas. Pemahaman terhadap nilai religiositas tidak dapat disamakan dengan aspek transpersonal. Hal ini karena psikologi transpersonal merupakan dimensi tingkah laku yang berhubungan dengan pengalaman transpersonal manusia.

Manusia sejatinya terdiri atas struktur personal dan transpersonal. Struktur transpersonal merupakan puncak dari usaha pengembangan potensi-potensi kemanusian yang paling tinggi. Pengembangan dimensi-dimensi transpersonal dapat dilakukan dengan pendalaman kehidupan kejiwaan yang bersifat spiritualistik Islami, seperti praktik

93 Benjamin Beit-Hallahmi, The Psychology of Religious Behavior, Belief, and Experience (London: Routledge, 1997), 75. 
sufisme. ${ }^{94}$ Karena itu, aktualisasi ritual nyadran dapat dipahami sebagai bentuk psikologi humanisme dalam membangun kesalehan sosial dan mempererat silaturrahmi. Akan tetapi, tidak dapat dijadikan kesalehan perilaku terutama untuk edukasi generasi muda khususnya tentang praktik lakon. Untuk memperkaya khasanah budaya tradisi lokal perlu melestarikan dan menjaganya dengan tidak mencederai nilai-nilai budaya bangsa dengan cara-cara yang tidak lazim atau tidak benar. Oleh karena itu, dibutuhkan edukasi dengan tetap mengedepankan nilai-nilai partikular, personal dan universal, sehingga self-esteem terjaga sepanjang zaman.

\section{Penutup}

Psikologi humanistik merupakan salah satu pendekatan psikologi yang mengedepankan aspek humanisme yang memandang manusia sebagai kekuatan dengan potensi-potensi yang sangat tinggi. Konstruksi teori Carl Rogers tentang psikologi humanistik memberikan kontribusi terhadap perkembangan psikologi dalam menganalisis perilaku manusia. Manusia terdiri atas struktur kepribadian yang meliputi organisme kepribadian, medan fenomena dan aktualisasi diri. Konsep Rogers dapat dijadikan pijakan dalam memahami perilaku manusia dan memanusiakan manusia sesuai dengan motivasi dan seluruh potensi yang dimiliki untuk dapat bekerjasama, penghargaan diri self-regard dan penerimaan diri self-esteem.

Implementasi humanistik pada ritual nyadran di Jambe Gemarang dapat dipahami sebagai proses pencarian jati diri pada sebuah komunitas di masyarakat. Masyarakat Jambe melaksanakan ritual nyadran dengan kesadaran sosial melalui iuran yang ditetapkan oleh kepala desa, sehingga semua keperluan untuk ritual nyadran dapat diatasi. Sikap humanis dari seluruh tokoh masyarakat dan tokoh agama menggambarkan masyarakat dinamis yang senantiasa mengedepankan kepentingan masyarakat dan menjalankan amanah warisan tradisi lokal nyadran.

Konstruksi psikologi humanistik Carl Rogers menyisakan problem dalam memahami ragam potensi manusia, karena sesungguhnya semua potensi manusia harus diidentifikasi berdasarkan nilai-nilai universalitas yang berlaku umum dan nilai-nilai yang bersifat subjektif. Oleh karena itu, konstruksi psokologi humanistik Rogers harus

\footnotetext{
${ }^{94}$ Fattah Hanurawan, "Kajian Psikologi Transpersonal terhadap Tradisi Sufisme
} Islam di Indonesia”, Jurnal Psikologika, Vol. 4, No. 8 (1999). 
dilakukan rekonstruksi dalam memahami potensi-potensi manusia khususnya yang bersifat particular, sehingga nilai-nilai humanisme tidak hanya berhenti pada konsep. Tetapi, juga dapat dipahami secara komprehensif. Nilai-nilai humanisme tidak hanya fokus pada pencapaian kepuasan berpikir diri sendiri, tetapi harus memahami pemikiran orang lain yang berbeda pandangan dengan dirinya.

Nilai-nilai aktualisasi diri dari tradisi ritual nyadran dapat dicapai melalui munculnya lakon pada kegiatan gambyong. Perilaku lakon merupakan aktualisasi diri yang mampu menghadirkan ketidaksadaran diri, sehingga menarik perhatian orang lain. Lakon menjadi pusat perhatian peserta ritual dan resi (orang yang mampu mengembalikan ketidaksadaran orang lain) meminta penjelasan terkait ritual nyadran yang telah dilaksanakan. Aktualisasi diri lakon memberikan motivasi dan percaya diri masyarakat untuk terus menjaga dan melestarikan ritual nyadran sebagai tradisi lokal. Lebih dari itu, nilai-nilai aktualisasi diri masyarakat Jambe Gemarang adalah jati diri yang memiliki kesalehan sosial, kesalehan diri dan kesalehan mencapai kebersamaan.

\section{Daftar Rujukan}

Adiansyah, Ryko. "Persimpangan antara Agama dan Budaya: Proses

Akulturasi Islam dan Slametan dalam Budaya Jawa", Jurnal Intelektualita: Keislaman, Sosial, dan Sains, Vol. 6, No. 2, 2017.

Ahmad, Maghfur. "Agama dan Psikoanalisa Sigmund Freud", Religia: Jurnal Ilmu-ilmu Keislaman, Vol. 14, No. 2, 2009.

Ajzen, Icek. Attitude Personality and Behavior. New York: Open University Press, 2005.

Alexis M., Prominents Feeling and Self-regard among Survivor of Suicide Does Time Heal All Wounds, Sage Journal, Vol. 25, No. 3, 2017.

Alwisol. Psikologi Kepribadian. Malang: UMM Press, 2016.

Amawidyati, Sukma Adi Galuh. "Religiusitas dan Psychological Well-Being pada Korban Gempa", Jurnal Psikologi, Vol. 34, No. 2, 2007.

Argyle, Michele. The Psychology of Religious Behavior Belief and Experience. London: Routledge, 2007.

Basir, Abdul. "Nilai Pendidikan Islam dalam Budaya Tenongan Nyadran Suran di Dusun Giyanti Wonosobo", Junal al-Qalam, Vol. 9, No. 2, 2012. 
Beit-Hallahmi, Benjamin. The Psychology of Religious Behavior, Belief, and Experience. London: Routledge, 1997.

Casram. "Membangun Sikap Toleransi Beragama dalam Masyarakat Plural”, Jurnal Wawasan, Vol. 1, No. 2, 2016.

Cortright, Brant. Integral Psychology. New York: New York Press, 2007. Faqihuddin, Achmad. "Internalisasi Nilai-nilai Humanistik Religius pada Generasi Z Dengan "Design for Change", Edukasia: Jurnal Penelitian Pendidikan Islam, Vol. 12, No. 2, 2017.

Geertz, Clifford. The Religion of Java. London: The University of Chicago Press, 1976.

Gumiandari, Septi. "Kepribadian Manusia dalam Perspektif Psikologi Islam: Telaah Kritis atas Psikologi Modern", Jurnal Holistik, Vol. 12, No. 1, 2011.

Hanurawan, Fattah. "Kajian Psikologi Transpersonal terhadap Tradisi Sufisme Islam di Indonesia", Jurnal Psikologika, Vol. 4, No. 8, 1999.

Hardjana, A.M. Penghayatan Agama: yang Otentik dan Tidak Otentik. Yogyakarta: Kanisius, 1993.

Harsanyi, John C. "Morality and the Theory Rational Behavior", JSTOR, Vol. 44, No. 4, 1977.

Hasanah, Hasyim. "Implikasi Psiko-sosio-religius Tradisi Nyadran Warga Kedung Ombo Zaman Orde Baru", Jurnal Wahana Akademika, Vol. 3 No. 2, 2016.

Hetler, Steven C. "Personal Persistensi and its Absence in Contemporary Life Narrative", Sage Journal, Vol. 57, No. 2, 2017.

Hikmawan. "Perspektif Filsafat Pendidikan terhadap Psikologi Pendidikan Humanistik", Jurnal Sains Psikologi, Vol. 6, No. 1, 2017.

Hisda, M. Ridwan. "Implementasi Pembelajaran Tafsir Alquran Pada Fakultas Agama Islam Universitas Dharmawangsa Medan”, Edu Riligia: Jurnal Ilmu Pendidikan Islam dan Keagamaan, Vol. 1, No. 3, 2017.

House, Richard. Humanistic Psychology Current Trend and Future Prospect. New York: Routledge, 2018.

Karen, Gideon (ed.), a Handbook for Data Analysis Behavioral Sciences: Methodological Issues. New York: Psychology Press, 2009.

Karyanta, Nugraha Arif. "Self-esteem pada Penyandang Tuna Daksa", Jurnal Wacana Psikologi, Vol. 5. No. 9, 2013.

Kosemin. Wawancara. Jambe Gemarang 21 November 2016. 
Krems, J.A., Kenrick, DT., Neel, R. "Individual Perceptions of SelfActualization: What Functional Motives Are Linked to Fulfilling One's Full Potential?", Pers Soc Psychol Bull, Vol. 43, No. 9, 2017.

Kumini. Wawancara. Jambe Gemarang 13 Desember 2016.

Kusman. Wawancara. Jambe Gemarang 28 Desember 2016.

Lailatul Fitriyah etc., "Effectiveness Behavioral Coating with Modeling Techniques and Assertive Training Techniques to Increase Confidence", The Bisma Journal, Vol. 1, No. 1, 2017.

Laksono, Joko Tri. "Fungsi Janggrung dalam Upacara Nyadran di Pantai Slili Tepus Gunung Kidul Yogyakarta”, Jurnal Harmonia, Vol. 9, No. 1, 2009.

Larsen Randy dan David Buss, Personality Psychology: Domains of Knowledge about Human Nature. New York: McGrave-Hill, 2008.

Lasiyem. Wawancara. Jambe Gemarang 19 Oktober 2016.

Lestari, Rizqy Kusuma dan Handayani, Sri Sularti Dewanti. "Children

Confidence Development by Theme Based Movement and Singing Method at RA Islamic Tunas Bangsa 4 Ngaliyan Semarang", BELLA: Early Childhood Education Papers, Vol. 6, No. $1,2017$.

Lisnawati dan Yunus. "Analisis Tokoh Utama dalam Novel Ashmora Paria Karya Herlinatiens: Psikoanalisis Sigmund Freud", Jurnal Bastra, Vol. 1, No. 4, 2017.

Mahmudah, Siti. "Mensinergikan Nilai-nilai Keagamaan dengan Tradisi Lokal sebagai Upaya Mewujudkan Masyarakat Madani: Studi Kasus Komunitas Kejawen di Desa Bajulan Kecamatan Loceret Kabupaten Nganjuk", Jurnal Konseling dan Pendidikan, Vol. 5, No. 1, 2017.

Marlina, Endy dan Ronald, Arya. "Ekspresi Budaya Membangun pada Masyarakat Jeron Beteng Kecamatan Kraton Yogyakarta", Jurnal Humaniora, Vol. 23, No. 2, 2011.

Martin, Garry. Modifikasi Perilaku: Makna dan Penerapannya. Yogyakarta: Pustaka Pelajar, 2015.

Marwan. Wawancara. Jambe Gemarang 11 Desember 2016.

----. Wawancara. Jambe Gemarang 29 Desember 2016.

Muhaya, Abdul. "Konsep Psikologi Transpersonal Menurut Abu Hamid Muhammad al-Ghazali", Jumal at Taqaddum, Vol. 9, No. 2, 2017.

Musringah. Wawancara. Jambe Gemarang 23 November 2016. 
Muzaki, Ahmad Wafi. "Humanisme Religious Sunan Drajat sebagai Nilai Sejarah dan Kearifan Lokal", Prosiding Seminar Nasional Pemanfaatan Smartphone untuk Literasi Produktif, 2017.

Nashori, Fuad. "Refleksi Psikologi Islami”, Jurnal Psikologi Islam, Vol. 1, No. 1, 2005.

Novitasari, Yuni. "Bimbingan dan Konseling Belajar (Akademik) dalam Perspektif Islam", Indonesian Journal of Educational Counseling, Vol. 1, No. 1, 2017.

Othman, Mohamad Fuad. "Pendidikan Rohani Berasaskan Sains AlQuran", Jurnal Comparative Education, Vol. 1, No. 1, 2017.

Partini. Wawancara. Jambe Gemarang 18 Oktober 2016.

Rahmahana, Ratna Syifa'a. "Psikologi Humanistik dan Aplikasinya dalam Pendidikan", Jurnal El-Tarbawi, Vol. 1, No. 1, 2008.

Rahman, Syaifur. "Kepemimpinan Transformasional di Lembaga Pendidikan: Kajian Sejarah, Psikologis, dan Pandangan Islam tentang Kepemimpinan", Junal Humanistika: Jurnal Keislaman, Vol. 3, No. 1, 2017.

Ratnawati. "Aspek-aspek Kejiwaan dan Motivasi Manusia dalam Konsepsi Islam", Islamic Counseling: Jurnal Bimbingan dan Konseling Islam, Vol. 1, No. 1, 2017.

Ratu, Bau. "Psikologi Humanistik Carl Roegrs Dalam Bimbingan dan Konseling", Jurnal Kreatif, Vol. 17, No. 3, 2014.

Rogers, Carl. Some Observations on the Organization of Personality. New York: American Psychologys, 2000.

Ruthven, K.K. Myth. New York: Routledge, 1976.

Sa'adah, Annas Fitria. "Konsep Diri Dalam Gaya Hidup Konsumtif Perspektif Teori Kepribadian Carl R. Rogers". Tesis--Universitas Gadjah Mada Yogyakarta, 2015.

Schultz, Duane. Psikologi Pertumbuban Model-model Kepribadian. Yogyakarta: Kanisius, 1991.

Shavelson, Richard J. "Self-Concept: The Interplay of Theory and Methods", Journal of Educational Psychology, Vol. 74, No. 1, 1982.

Shavelson, Richard J. "Selt Concept: Validation of Construct Interpretations", Sage Journal, Vol. 46, No. 3, 1976.

Shettleworth, Sara J. Cognition, Evolution and Behavior. New York: Oxford University Press, 2005.

Siregar, Nurul Fadhilah. "Hubungan Kepercayaan Diri dan Dukungan Orangtua dengan Kemampuan Membuat Aksesoris 
dari Limbah Kulit Jagung Siswa SMP Negeri 34 Medan”. Skripsi-Universitas Negeri Medan Medan, 2017.

Skinner, B.F. Verbal Behavior. Cambridge: Prentice Hall. Inc, 2014.

Slamet. Wawancara. Jambe Gemarang 12 Desember 2016.

----. Wawancara. Jambe Gemarang 17 Oktober 2016.

----. Wawancara. Jambe Gemarang 23 Desember 2016.

Sumarsono. Wawancara. Jambe Gemarang 11 Oktober 2016.

----. Wawancara. Jambe Gemarang 20 Oktober 2016.

Sungkono. Wawancara. Jambe Gemarang 20 November 2018.

Supratiknya. Psikologi Kepribadian 1: Teori-teori Psikodinamik (Klinis).

Yogyakarta: Kanisius, 1993.

-----. Psikologi Kepribadian 2: Teori-teori Holistik Organismik Fenomenologis.

Yogyakarta: Kanisius, 1993.

Suryani, Nidia. "Hubungan Self Esteem dengan Sikap Sosial Remaja

Serta Implikasinya dalam Layanan Bimbingan dan Konseling di

SMA Dabiah Padang", Ristekdik: Jurnal Bimbingan dan Konseling,

Vol. 3, No. 1, 2017.

Susanto, Edi. "Krisis Kepemimpinan Kiai: Studi atas Kharisma Kiai dalam Masyarakat, Islamica: Jurnal Studi Keislaman, Vol. 1 No. 2, 2007.

Suwarno. Wawancara. Jambe Gemarang 19 November 2016.

Suyono. Wawancara. Jamber Gemarang 18 November 2016.

Thahir, Lukman S. "Islam Ideologi Kaum Tertindas: Counter

Hegemoni Kaum Marginal dan Mustad'afin", Jurnal Studi Islamika Hunafa, Vol. 6, No. 1, 2009.

Utomo, Cahyo Budi dan Kurniawan, Ganda Febri. "Bilamana Tradisi

Lisan Menjadi Media Pendidikan Ilmu Sosial di Masyarakat Gunungpati”, Jurnal Harmony, Vol. 2, No. 2, 2017.

Winarti, Tutik. "Tari Golek Gambyong Gaya Yogyakarta", Jurnal Resital, Vol. 11. No. 1, 2010.

Winter C.F. dkk., Kamus Kawi-Jawi. Yogyakarta: Gadjah Mada University Press, 2003.

Yusanti, Elva. "Struktur Kepribadian Tokoh Utama dalam Novel Nyali Karya Putu Wijaya", Mlangun: Jurnal Ilmiah Kebahasaan dan Kesastraan, Vol. 12, No. 2, 2016.

Zoetmulder, P. J. dkk., Kamus Jawa Kuno Indonesia. Jakarta: Gramedia Pustaka Utama, 1982. 